Aldona Kopkiewicz

\title{
Chroboty, echa, oho! Słuch i inne zmysły w poezji Mirona Białoszewskiego1
}

Tu, wśród gasnacych, bądź, w królestwie nocy,

bądź szkłem dźwięczącym, co się rozbiło już w dźwięku.

Rainer Maria Rilke, Sonety do Orfeusza (II, XII)

„[... ] poezja tak naprawdę istnieje tylko w czytaniu na głos. W pelnym słyszeniu. I to jest materia, słuchowa" [Białoszewski 2009: 149]. W zacytowanej rozmowie Miron Białoszewski przedstawia Jadwidze Stańczakowej poezję jako sztukę niematerialną: z materii słuchowej, a więc czystego dźwięku i powietrza, ducha i życia. Albo - jako sztukę materialną właśnie: nieodłączoną od osoby, ciała i głosu autora. Poeta nowoczesny - w tym przypadku Miron Białoszewski - nie słucha już głosów transcendentnych, ale szumu topoli za oknem, melodii szafy, chrobotów ścian własnego pokoju oraz innych ludzi. Im niższe, zwyklejsze, powszedniejsze doznania zmysłowe, tym lepiej, bo jeśli gdzieś czekały jeszcze jakieś pozostałości poetyckości, minionej magii słowa i rzeczywistości, to w tych codziennych ruinach, małych świętach materii². Rzeczywistość ta udostępniała się poecie afektywnie i zmysłowo - i właśnie

1 Projekt został sfinansowany ze środków Narodowego Centrum Nauki przyznanych na podstawie decyzji numer DEC-2012/05/N/HS2/0266o.

2 Blisko mu w tym oczywiście do Schulza, Benjamina czy Kantora i innych artystów zaintrygowanych rzeczywistością ubogą [Por. Sandauer 1968; Nycz 2001; Lipszyc 2014]. 
jako taka stanowiła źródło twórczych możliwości. Aby opisać tę dynamikę doznawania i zapisywania, posłużę się obrazem podmiotowości wypracowanym przez Jean-Luca Nancy'ego w eseju Nasłuchując ${ }^{3}$, pozwala on bowiem zrozumieć, czym dziś jest słuch poetycki i w jaki sposób to, co zasłyszane zostaje przekształcone w znaczenia wiersza. Dzięki francuskiemu filozofowi właśnie jesteśmy w stanie uchwycić materialne, zmysłowe ślady i odczytywać je tak, by nie zamieniały się od razu w znaki - tak, by nie traciły swojego empirycznego pochodzenia.

Nancy rozpoczyna swoje rozważania od ukazania różnicy między tym, co w filozofii widziane, a tym, co słyszane: metafory wzroku mówią o zdolności do przedstawiania i teoretyzowania. Zmysł słuchu wiąże się z wycofaniem i uwewnętrznianiem; z duszą, w której rezonuje - brzmi, dźwięczy, wibruje, porusza - to, co zasłyszane. Wzrok domaga się natomiast ukazania i ujawnienia. Słuch, podobnie jak dotyk, wydaje się zmysłem służącym Nancy'emu do wyprowadzania nowej wizji podmiotu, a wizja ta rodzi się dokładnie tam, gdzie stykają się ekstrema spekulacji i empirii, idei i doznania, sensu i sensualności wreszcie.

Słyszeć znaczy także tyle, co rozumieć: samo nasłuchiwanie wyraża napięcie i sens, podczas gdy rozumienie kieruje nas w stronę równowagi i prawdy; przede wszystkim jednak: „Słuchać to być na krawędzi znaczenia (...) tak jakby dźwięk nie był niczym innym jak tylko tą krawędzią, tym obrębkiem, tym marginesem” [Nancy 2007: 4]. Granica ta jest istotna, skoro wskazuje na miejsce przecięcia, spotkania, wymiany i innych wzajemnych oddziaływań między podmiotem i rzeczywistością - na tej granicy dochodzi do rezonansu, przemiany tego, co sensowne w to, co sensualne i na odwrót.

Nancy nie zajmuje się granicą po to, by ją znieść, ale właśnie przywrócić ${ }^{4} \mathrm{w}$ nowym świetle, czy też wydobyć nowy tembr jej istnienia. Czym może być zatem wspólna przestrzeń dźwięku

4 Po Derridzie, który nadwerężył ją wystarczająco mocno we wspomnianym Tympanum. Tympan to nie tylko bębenek, ale i prasa drukarska. Derridę zainteresowało oczywiście otwarcie na odcisk znaków, typografię wdzierającą się do wnętrza, a zatem utrata granicy „ja” i tekstu, co właśnie najbardziej niepokoi Nancy’ego, zdecydowanego krytyka Kolonii karnej Kafki, filozofa, który chce 
i znaczenia? Znaczenie zawiera w sobie odniesienie. Odniesienie natomiast powoduje opóźnienie: odwlekanie rozgrywające się między znakiem i rzeczą, między wnętrzem i zewnętrzem podmiotu, a w końcu między ludźmi. Podobnie dźwięk: rozchodzi się i rozbrzmiewa w przestrzeni, odbija zarówno w niej, jak i we „mnie”. Wnętrze i zewnętrze stają się przestrzeniami odbijających się od siebie oddźwięków, oddziaływają one na siebie, wpływają na siebie nawzajem, a potem, odbite, rozbrzmiewają znów we wnętrzach, by po czasie znów wprawić wszystko w ruch odniesień. Tak wyraża się relacja dystansu, ale tak też w ogóle zawiązuje się relacja. Choć zatem oddziaływania są dalekie, choć między ich aktorami przebiega granica, to także jedyna droga, by zaistniał dotyk, wiązanie, zbliżenie. Ale nigdy takie, by zatrzeć odrębność podmiotów, słów i rzeczy.

Podmiot czuje: słyszy się, widzi się, dotyka się i smakuje; to czucie umożliwia zbliżanie się do siebie, natomiast odniesienie do „ja” - dystansowanie. Praca świadomości odbywa się bowiem nieustannie i choć trudno wyznaczyć tu granicę między afektem i auto-afektem, możliwość odnoszenia do „ja”, pozostaje warunkiem podmiotowości, jej autonomii i wolności. Tożsamość „ja” pozostaje w ruchu, w ciągłym odnoszeniu, rezonowaniu do siebie, do innego, do czegoś - i w drugą stronę, rezonowanie to bowiem także przyjmowanie oddźwięków rzeczywistości. Bliskie figurom dotyku i zdarzenia słuchanie umożliwi wobec tego refleksję nad afektywną i zmysłową sferą podmiotowości poezji Białoszewskiego, choć, by nie stracić konkretnej rzeczywistości słuchania, będę śledzić poetycką ekspresję właśnie zmysłu słuchu. Wprawdzie gra on też istotną rolę w prozach, został już jednak dostatecznie opisany ${ }^{5}$; ma tu ponadto nieco inną naturę, bardziej społeczną i historyczną, tak jakby poezja wciąż była uprzywilejowanym miejscem poznawczych i ontologicznych odkryć.

przywrócić możliwość wnętrza i autonomii „ja”, gdy „ja” jest zanurzone „po uszy” w relacji z innymi i w rzeczywistości [por. Derrida 2002].

5 Sferę słuchową i wizualną interpretowała już Agnieszka Karpowicz, jej badania jednak odnoszą się głównie do Chamowa, a zatem do prozy, i eksponują społeczny wymiar zmysłów, ewentualnie czysto fenomenologiczny, od którego staram się odejść [por. Karpowicz 2012]. 
Białoszewski po wojnie odwlekał ekspresję traumy; próbował za to ożywić upadły, szczątkowy świat i odkryć swoistą cudowność ocalonych rzeczy. Pierwsze próby wydobycia owej niezwykłości odbywają się poza zrujnowaną Warszawą, na prowincji (Ballady rzeszowskie, Ballady peryferyjne) i we własnym pokoju. Własny pokój to przestrzeń odcięcia i samotności, konfrontacji z wnętrzem. Jednocześnie jest to przestrzeń najbardziej podstawowa, niejako pierwsza - kryjówka, w której ciało poety osiąga stan wyzerowania, czystego wyczulenia. To tędy - przez skórę - prowadzi droga do rozpoznania warunków, w których „ja” i rzeczy stają się rzeczywiste.

Doświadczenie obecności siebie i świata nie daje się wpisać ani w sferę ontologii, ani czystej percepcji. Jest możliwe dzięki afektywnemu nastrojeniu piszącego podmiotu. Percepcja ma swój początek w konkretnym ciele, nie ma zaś ciała bez pamięci i właściwości; także ciało Białoszewskiego nie może być neutralne, przynajmniej dopóki ma poczucie, że żyje. Właśnie dlatego trauma przypomina śmierć - stan odłączenia od zmysłów i afektów, siebie i języka; stan wyrażający niemożliwość czucia po wydarzeniu, które wstrząsnęło jednostką zbyt mocno. Trauma oddziałuje przede wszystkim na zmysły i emocje, a przez nie na świadomość, można ją nazwać afektem negatywnym. Jej symptomy bywają różne, u Białoszewskiego wydaje się ona przede wszystkim podłożem nowoczesnego znużenia, które przeżywał w trakcie słynnych leżeń ${ }^{6}$. Pogrążony w melancholii, leżący w łóżku Białoszewski zbliża się wprawdzie do takich stanów, lecz, co istotne, nie trwa w nich a uporczywie próbuje się wydobyć przy pomocy poezji, wiele jego wierszy mówi właśnie o samej pracy przezwyciężania letargu. Poeta wyczekuje na sygnał z rzeczywistości, lecz sam także zaczyna z czasem wytę-

„Melancholią nazwiemy ochronną symptomatologię zahamowania czynności [inhibition] i utraty zdolności rozumienia symboli [asymbolia], która pojawia się chwilowo lub chronicznie u jakiejś osoby, najczęściej naprzemiennie z tak zwaną maniakalną fazą nadmiernego pobudzenia”. Podmiot jest niezdolny zarówno do symbolizacji, jak i jakiejkolwiek innej stymulacji, staje się samym ciałem, a to tak, jak gdyby umarł [cyt. za: Kristeva 2007: 11].

7 Na lękowo-abuliczny stan podmiotu wczesnych wierszy zwracał już uwagę Jerzy Kwiatkowski [por. Kwiatkowski 1964]. 
żać wzrok, słuch i wszystkie inne zmysły po to, by jego otoczenie mogło stać się materią wiersza. Afektywne otwarcie prowadzi w końcu do relacji zwrotnej: sam poeta rozbrzmiewa przychodzącymi z otoczenia wrażeniami, zapoczątkowując cyrkulację obrazów i dźwięków, wizji i oddźwięków, z których wyłania się jego egzystencja, a więc także - poezja ${ }^{8}$.Obroty rzeczy zostały właśnie tak skomponowane, by w trakcie lektury krążyć po orbicie poety w kierunku jego wnętrza. Zaczynają się wierszami prowincjonalnymi, po nich zaś przychodzi kolejny etap: własny pokój, który wybrzmiewa dzięki świadomości poety. I nie gra tu bynajmniej świadomość czysta, doznanie i pisanie okazują się możliwe o tyle, o ile pośredniczy między nimi sztuka. W skrócie tendencja ta daje się opisać dwoma tytułami z interesującego mnie teraz cyklu: szare eminencje zachwytu - sztuki piękne mojego pokoju.

Nawiązania do muzyki klasycznej wydają się najbardziej naturalne, gdy chodzi o Białoszewskiego. Nie są to ani zwykłe onomatopeje, ani też dialogi z historią muzyki ${ }^{9}$; siedzący w pudle rezonansowym swojego pokoju poeta oswaja rzeczy, czyni je materiałem wiersza, wybierając za punkt styku dźwięk nazwy, którą przekształca w niemalże czyste brzmienie - doprowadza ją do stanu, kiedy znaczenie słowa przestaje grać wielką rolę, a zaczyna obracać się wraz z przekształcanym brzmieniem słowa. Rzecz materializuje się w dźwiękowej, muzycznej sferze wiersza, a zatem to poezja ożywia ją niczym nieme przedmioty w baśniach. Wydobyty z rzeczy dźwięk, a właściwie wydobyta muzyka, wyzwala stany oczarowania i fascynacji, zamieniające się w chwilę ekstazy. Pośrednictwo sztuki wskazuje, że to nie sama rzecz, ale skojarzenie ze sztuką czy wręcz zabawa magią dają początek iluminacjom.

8 Podobnie o poezji Białoszewskiego pisał Tomasz Kunz, nie zajmował się jednak samą afektywnością i zmysłowością poety, ale rolą pisma w jego projekcie egzystencjalnym i szerzej konstytucją podmiotowości w samym tekście [por. Kunz 2006].

9 Odniesienia do historii muzyki i struktur muzycznych są w poezji Białoszewskiego istotne, choć nie w kontekście, który tu podejmuję. Taką analizę przeprowadził Jerzy Wiśniewski, który uznaje, że struktury muzyczne niosą w sobie głębokie doświadczenie istoty rzeczywistości, domniemanej metafizycznej harmonii i szeroko pojętego ducha [por. Wiśniewski 2004]. 
Na nie z kolei mimowolnie oddziałuje też pamięć. Traumatyczne ślady pojawiają się w tej poezji nagminnie, dlatego pokażę całą tę kwestię, odczytując wiersz Sztuki piękne mojego pokoju [Białoszewski 1987: 65-68]:

1. Szkoła śpiewu

Szafo szafo Semiramido

$$
\text { piramido }
$$

Aido

opero w trzech drzwiach!

$(\ldots)$

Jeden powiedział:

taki żydowski kloc -

ta szafa to Golem.

\section{(...)}

3. Szkoła nieprzyzwyczajenia

\section{( (..)}

\section{Wieczorem}

dotknąć kroju krzesła -

brzdąknąć na byle linii siennika -

posmakować suchy okruch sufitu -

to wpadają stadami

wszystko co się skojarzy

jak ćmy -

czego by nie pomyśleć.

Tyle ich! Tyle ich!

Aż krążymy i my -

i wołamy (ja, piec, sienniki):

„Aniołki - aniołki

siadajcie na ścianie

$$
\text { tu tu!!!” }
$$

Siadają.

Śpiewają gamę: 
do

my

sły

rze

czy

wi

sto

ści

rze

czy

wi

sto

ści

do

my

sty

— - Uczepiony jej pająk mojego pokoju

a to - już się rozwidnia.

Puste oka mrugają firankę.

Teraz tylko - przeznaczenie

welon Ananke -

albo bogini zmęczenia

byleś tylko nie zesłała

do rzeczy przyzwyczajenia.

Już w pierwszej części wiersza powtórzona apostrofa do szafy opiera się o mocny rym i aliterację - Semiramida, piramida i Aida zostały zrymowane nie tylko ze względu na podobieństwo brzmienia, ale dlatego, że ich echo pojawi się w późniejszej gamie, a ta ułoży się w „domysły rzeczywistości” w trzeciej części tekstu. Rzeczywistość ożywa dla Białoszewskiego, gdy jest postrzegana jako materia muzyczna - staje się zrozumiała i sensowna, kiedy można ją opisać słowem, którego dominantą jest dźwięk, i to nie przypadkowy dźwięk, przygodny hałas, a poetycka dźwięczność słowa, która właśnie niesie w sobie myśli i sens, sama domyśla 
się swoją materialną rzeczywistością - zaraz skojarzy się przecież $\mathrm{z}$ gamą muzyczną, ta zaś okaże się równoznaczna $\mathrm{z}$ „domysłami rzeczywistości”, wyśpiewywanymi przez „aniołki”. Właśnie „domysły rzeczywistości” - założona, być może intuicyjnie odczuwana, sensowność rzeczywistości zostaje wyrażona w gamie dźwięków sensowność ta nie istnieje bowiem w nagiej materii, ale tej już rozruszanej przez dźwięk zapośredniczony zarówno w sztuce, jak i w głosie. „Aniołki” z kolei to zdrobniałe figury minionej, metafizycznej poezji, najwyższego objawienia i posłannictwa. W tym wierszu stają się one metaforą ożywiającego pokój poruszenia. Drgania we wnętrzu rezonansowego pudła pokoju powstają jednak dzięki zmysłom „ja”, mają swój początek wraz z „dotknąć”, „brząknąć”, „posmakować”, a cała sytuacja rozgrywa się wieczorem, wtedy, gdy widzialny świat zaciera się i bliższe ciału zmysły dochodzą do głosu. Poeta znajduje się bowiem w swoistym kokonie: odgradzające go od świata firanki to dzieło pająka, i dopiero kiedy nadchodzi świt, zaczynają prześwitywać „pustym okiem”, groźbą znużenia, wyłączenia zmysłów na rzecz fatalistycznego przyzwyczajenia do codziennych widoków.Ponadto w Szkole śpiewu pojawia się jeszcze pragnienie śpiewania arii - „Gdybym umiał śpiewać w tobie / ach / spróbuję arii O szafo”. Kiedy rozpoczynamy lekturę wiersza, wydaje nam się, że podmiot inscenizuje rodzaj śpiewu - wyobraża sobie siebie jako legendarną królową lub operową heroinę - potem jednak okazuje się, że muzyka, a właściwie prosta gama, wybrzmi dopiero pomiędzy czującym ,ja” i jego otoczeniem. Dlaczego podmiot chce śpiewać w szafie? I dlaczego nie umie? Czy dlatego, że jest zbyt „rozwidniona”, „błyszczy w cztery płaskie świece”? Czemu szafa tak odróżnia się od innych rzeczy, bije niezwykłym, choć złamanym światłem? Kiedy poeta próbuje arii, szybko przerywa, przypomina sobie bowiem, że ktoś nazwał szafę „żydowskim klocem”, „Golemem”. Pamięć o Żydach związana jest w twórczości Białoszewskiego z traumą II wojny światowej, być może więc w szafie tej nie da się śpiewać, skoro stanowi ona miejsce pamięci o Zagładzie. Golem był ponadto istotą pozbawioną duszy, niezdolną zatem do mowy. Nie stworzył go Bóg, więc otaczała atmosfera śmierci. W pokoju Białoszewskiego stoi zatem przedmiot będący tylko milczącą materią, szafa ucieleśnia- 
jąca traumę wojny, która milczy i w której nie rozlegnie się nawet głos „ja”. To tajemnicze, groźne miejsce, niepojęte materialne monstrum, stawiające opór udźwiękowieniu i usensownieniu.

Zanim jednak Białoszewski przepracuje największą traumę swojego życia w Pamiętniku z powstania warszawskiego, będzie się jeszcze musiał wyleżeć, do końca odczuć bezwładność i samotność tak, by przestroić się afektywnie - wyjść z traumy i odnaleźć drogę do stanów epifanijnej gotowości. W Obrotach rzeczy zapowiedź tej tematyki - w pełni rozwiniętej w Rachunku zachciankowym i Mylnych wzruszeniach - stanowią cykle Liryka sprzed zaśnięcia i Autoportrety. Doświadczenie znużenia staje się punktem wyjścia refleksji nad dostępnością zmysłów i samą możliwością pisania poezji. Wystarczy przywołać następujące niemal po sobie Moje Jakuby znużenia, Autoportret odczuwany, Autoportret radosny i Nie umiem pisać. W Leżeniach poeta próbuje zaczepić się o konkret, materię, popadł bowiem w bezwładność absolutną - nawet swoje zgięte podczas leżenia kolana nazywa górą Karmel. Wokół tej góry będą kręcić się odczucia i spostrzeżenia „ja”, drobne refleksje, notatkowe wiersze, opisujące brak natchnienia. Na zgiętych kolanach leży przecież kartka, a próbuje przerwać stan bezwładności, mówiąc na głos. Wierzy, że usłyszane słowo pobudzi go do pisania, ale jest w stanie wydobyć $\mathrm{z}$ siebie tylko głoski i cytaty, te zaś zaraz topią się w jego ciele. Znajdują się bowiem zbyt daleko, nie dają się złapać w teraźniejszość doznania - odwlekanie nie może być zatem za długie, bo nie wytworzy rezonansu, a jedynie poświadczy rozregulowany czas: ujawni moc, z jaką ,ja” wypadło z rzeczywistości. Mówi o tym na przykład wiersz roztopienie się we mnie cytatu: „powiedziałem swojemu weselu ciesz się" [wyróż. A.K.], lecz wesele znajduje się „100 km / ode mnie do siebie” i kolejne 100 do „rozkazu siebie”. Mimo to na końcu pojawia się nadzieja: „i tak / cud / że się słyszy” [Białoszewski 1987: 266]. Samo więc doznanie zmysłowe wyciąga poetę z bezwładności, na razie wprawdzie tylko odrobinę ponad powierzchnię kołdry, lecz już ta odrobina wystarcza, by napisać wiersz. W finale cyklu pojawiają się dwa wiersze, w których widziałabym źródła późniejszych eksperymentów językowych: przekręcania słów, poetyckich gier między mową i zapisem. W na jesiennej osobności [Białoszewski 
1987: 271] z leżenia wyłania się głoska „o”, bo „chce się być osobno”, lecz wyłania się ona także: „z otworzenia ust” - splata się tu, choć nie chce związać, osobność z otwarciem. Głoska „o” krąży - ze względu na oddech „płynniej o samogłoski”, a „spółgłoski krztuszą" - po czym poeta i tak wpada z powrotem w ciszę. Na samym już końcu cyklu znajduje się za to utwór polka $z$ soba [Białoszewski 1987: 276] i dopiero tu poecie udaje się w końcu przezwyciężyć osobność:

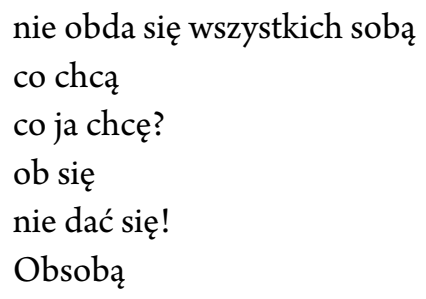

Głoski stają się mostem między „o” osobności i światem „obda” od obdarzania to za dużo, nawet jeśli poeta zdaje się afirmować fakt, że nie będzie pisał dla wszystkich. Pyta zatem „co ja chcę?” i odpowiada „ob się”, by stać się „obsobą”, co odczytywałabym jako deklarację wyjścia z osobności, ale w taki sposób, by zachować jedność i tożsamość własnego „ja”; tak by znać swoje granice, symbolizowane dwoma zamkniętymi okręgami „ob”. Po tym wierszu następuje przecież cykl Zajścia, w którym Białoszewski po raz pierwszy tak mocno udostępnia swoje wiersze obserwacjom rzeczywistości, zmierzając już do próz; w tym cyklu można również znaleźć dwa wiersze szumię, w których dochodzi do przemieszczenia „ja” z zamkniętej introwersji na granicę między wnętrzem i zewnętrzem. Na niej właśnie dochodzi do utożsamienia zmysłowego doznania z samą możliwością pisania, i to poetyckiego, nastawionego na brzmienie, choć także odkształcanego przez zapis, jak widzimy w szumię (dwa) [Białoszewski 1987: 301]:

$$
\begin{aligned}
& \text { co ja słyszę? } \\
& \text { pisze(ę) } \\
& \text { się }
\end{aligned}
$$


bo

szumi(ę)

W późniejszych wierszach Białoszewskiego percepcja dźwiękowa pojawia się coraz częściej, ale prawie w ogóle nie posiada już wymiaru muzycznego. Zbliża się do figury, pozwala się odczytywać metaforycznie; na pograniczu metafory i doznania pogłębia się jej spekulatywny wymiar. Dźwięki przychodzą z zewnątrz i odchodzą, zjawiają się jak ulotny ślad czegoś, co nie daje się pochwycić - są to zarówno zapiski ontologiczne, jak i historie o czymś, czego nie może dojrzeć w pokoju, więc budzi lęk; czasem drażni lub zaskakuje, jak hałasy sąsiadów; niejednokrotnie chodzi też o jakiegoś ducha, a dźwięk staje się chrobotem pamięci o nieobecnym. Świat dźwięków mówi o tym, co jeszcze (lub już) w rzeczywistości niepojęte; niewidzialne i niemożliwe, więc przeczuwane przez poetę. Te epifanie nie są ani objawieniem sensu, ani nicości - są czymś połowicznym, mgnieniem i szmerem - są ruchem $\mathrm{z}$ nicości do bytu, przemianą istnienia $\mathrm{w}$ nieistnienie, nawiedzaniem. Wprawdzie i pierwszy cykl z tomu Oho, Namysły i rozmysty, rozpoczyna się od stanów leżenia i odrętwienia, $\mathrm{w}$ których doznania zmysłowe utwierdzają jedynie poetę $\mathrm{w}$ bezwładności i przywołują minioną traumę: „rura w głowie / buczy / zgłupienie / już leżę” - to $\mathrm{z}$ wiersza o incpicie chodzenie [Białoszewski 2010: 10], zaraz za nim pojawia się zaś utwór moja głowa była Żydem [Białoszewski 2010: 11]. Ale poeta będzie wstawał i chodził mimo to, wędrował tak, by odkryć stany niepełne i niecodzienne: przechodzenia, polatywania, kołowania. Białoszewski szuka pobudzeń, dzięki którym będzie mógł odbić się lekko od rzeczywistości; lekko, a więc nigdy tak daleko, by odlecieć od niej całkowicie. Lekko, więc w gotowości na jej pierzchanie i przemijanie, ciągły ruch, który tyleż pobudza, co męczy swoją krótkotrwałością. Te stany obrazują niepokój, poeta jasno bowiem mówi, że odczuwane i obserwowane przezeń związki „istnienia z nieistnieniem” nie mają charakteru pojednania, lecz walki: „I tu nie wierzyć / w białe porozumienie / istnienia $\mathrm{z}$ nieistnieniem ... (?)...”, a zaraz potem: „istnienie / przez nieistnienie / ciągnięte za włosy" [Białoszewski 2010: 82]. 
Fragmenty te pochodzą z cyklu Garwolin w zimie, w którym śnieg właśnie staje się metaforą ciszy i pustki. Tych zaś najwyraźniej należy się wystrzegać, o czym mówi wiersz (ucho do śniegu) [Białoszewski 2010: 84]:

1

\section{Ucho do śniegu}

jak do muszli

u w a ż a ć!

przylipnie

2

szyja wyciąga się do okna

tam

ostrość śniegu

rozdziawiona

może ciachnąć!

Przyłożenie ucha do śniegu kojarzy się podmiotowi z przyłożeniem go do muszli, w której słychać oczywiście szum morza. Ale to tylko złudzenie, słychać przecież jedynie szum krwi. Ponadto samo ucho ma na zewnątrz kształt muszli, w środku zaś dopiero kryje się to, co należy do sedna słyszenia - aparat ucha wewnętrznego. Podmiot $\mathrm{w}$ tym wierszu przykłada natomiast ucho do śniegu, czyli zmarzniętej wody pokrywającej ziemię, lecz pod tą powierzchnią nie usłyszymy nic, choć grozi nam zasłuchanie trzeba uważać, by ucho nie przymarzło do lodowatej płaszczyzny. Usłyszeć można wówczas jedynie zimną pustkę, wieczność, która mami głębią, lecz jest jedynie odbiciem nas samych.

Jak zatem słuchać tego, co pomiędzy, na granicy wnętrza i zewnętrza? Przede wszystkim należy trzymać się tego, co istnieje najzwyczajniej i co daje się doświadczyć zmysłowo; chodzi jednak o takie istnienie, które może stać się pobudką poezji. Białoszewski wie, że potrzebuje najbardziej konkretnej, empirycznej 
rzeczywistości; mimo to nie afirmuje jej w całości, nie przyjmuje wszystkiego. Zachowuje dystans i podtrzymuje ambiwalentne odczucia wobec niej, jak w wierszu Faktyczność [Białoszewski 2010: 127], kiedy poeta i rzeczywistość nawzajem na siebie chrząkają, aż w końcu on rzuca jej „ty świnio”. Te odczucia staną się prawdziwie dramatyczne, gdy będzie musial zmierzyć się z najtrudniejszą materią - własnym umierającym ciałem. Odtrutką na traumę znów okaże się zdarzenie zmysłowe, konkret; tym razem obmierzły, najniższy, jak w pierwszym wierszu z cyklu Ja $i$ wczasy na leżąco [Białoszewski 2010: 181]:

cisza
a umie
nagle mruga
w uchu
a to ta druga:

mucha

Mucha będzie bohaterką wielu jeszcze wierszy - „śpiewaczka nocy była jedna / mucha” - a uparte, ciągłe bzyczenie i polatywanie much pod sufitem sprawi, że staną się one sprofanowanym obrazem wieczności. To, co rzeczywiste - a w tym przypadku dość wstrętne i niskie - pozwala potraktować groźną wieczność przewrotnie, osłabić jej moc i obecność. W tym sensie muchy są odwrotnością śniegowej bryły, a obserwując je, można zostać świadkiem sceny, w której ów duch ginie; przy odrobinie szczęścia można nawet samemu go zabić (duch ma zatem dwa oblicza, ożywiające, gdy wskazuje na ruch, a więc na ciało, i śmiercionośne, gdy wyraża wieczność). Jak bowiem poeta pisze w ostatnim wierszu tego cyklu, Antydodatek [Białoszewski 2010: 194-185], właśnie owo małe życie, ciało prowokujące rzeczywistość do niewielkich nawet ruchów i zdarzeń, umożliwia życie piszącemu „ja”:
a jednak
póki się żyje
i co innego żyje
skrobie 
to nie tylko duch

choćby przelatujący

ale i cało

małe

bo zamieszkała między nami

szafami

a czasami

mysz

migoty

muchy tez

bronią cisz

(...)

W cyklu Odmiany łapania tchu słyszy siebie: leży w szpitalu i słucha już tylko swojego chrapliwego oddechu; znamienia życia i poezji. Zapisując brzmienie oddechu, „ja” poświadcza dźwięki stanu niemalże przedśmiertnego. Duch, który symbolicznie pojawia się jako gołębica, nie tylko wzlatuje, ale też grucha, a potem rzęzi ze śmiechu [Białoszewski 2010: 276]:

dech się skraca

odfruwa

powalonego duch rozpruwa

sam ze śmiechu rzęzi

że tak im dobrze było

na uwięzi

obu

zmyślonym

Śmiech to niby straszny, ale i przewrotny, „że tak dobrze im było” - „zmyślonym”. U kresu dni Białoszewski wyjątkowo mocno odczuwa niezdolność języka, a zwłaszcza metafor, do wyrażenia stanu, w jakim się znajduje. Wszystkie opadają i rozbijają się o ciało. W wierszu Choroba [Białoszewski 2010: 282] z 26 maja 1983 pisze: 
nie wychylać się

dosłownie

nie rozruszać

dosłownie

mszczą się zużyte metafory

a dosłowności biologiczne

to potwory

ja - ich skrzyżowanie

pokrzyżowanie siebie sobie

czego się wypieram?

możliwości?

które się czaily

jeszcze coś z czegoś wybieram

jeszcze się czają niemożliwości

„Jeszcze coś z czegoś wybieram”, bo otwartość podmiotu nie polega na przepuszczaniu przez siebie całej rzeczywistości, na afirmacji wszystkiego, lecz na aktywnym, świadomym poszukiwaniu doznań, które pozwolą przekształcić się w poetycką metaforę - doznań niemożliwych. A niemożliwe jest w poezji właśnie przekształcanie tego, co zmysłowe, w to, co poetyckie: sensualności w sens, konkretu w spekulację tak, by nie przeważyła żadna ze stron opozycji. Poezja uobecnia się więc, jak chciał Nancy, na granicy, i eksponuje tym samym jednoczesność ducha i ciała w niemożliwym, niezwykłym zestawie słów, które same działają estetycznie swoim zmysłowym kształtem, a jako takie nie dają się zawłaszczyć ani faktyczności, ani filozofii.

Takie słowo pojawia się wraz z narodzinami niepokoju, z afektywnym pobudzeniem - drżeniem serca, które wyraża najbardziej jednostkowe odczucie świata. To odczucie rodzi się jednak w relacji, w rezonansie rzeczy i głosów, a poeta nigdy nie jest w stanie zawłaszczyć rzeczywistości swoim dziełem - nigdy nie jest w stanie nazwać jej do końca. Poetyckie ułomki, fragmenty i kamyki, 
które pisze i zbiera, stanowią przeciwieństwo wielkiej narracji; to właśnie one pobudzają pisarza do życia, zachęcają, by wciąż i wciąż ponawiać trud wypatrywania i wysłuchiwania, dotykania miejsc, w których pojawia się nowa (nie)możliwość, w których jakaś chropowatość zaprasza, by wypowiedzieć jej nieoczekiwany sens. To w momentach kryzysów, wznoszenia i opadania, udostępnia się natura procesu pisania; jednocześnie poeta winien dążyć do przestrojenia, przekształcenia traumy w afekt nieokreślony, a gotowość ciała będzie tu zbiegać się z pracą pisania: ciało i słowo oddziałują na siebie nawzajem, a od napięcia między nimi powinno szemrzeć i iskrzyć.

\section{Bibliografia:}

Białoszewski Miron (2009), Chamowo, Państwowy Instytut

Wydawniczy, Warszawa.

Białoszewski Miron (1987), Obroty rzeczy. Rachunek zachciankowy. Było i byto. Mylne wzruszenia, PIw, Warszawa.

Białoszewski Miron (2000), „Oho” $i$ inne wiersze, PIW, Warszawa.

Derrida Jacques (2002), Tympanum, przeł. Janusz Margański, w: tegoż,

Marginesy filozofi, Wydawnictwo KR, Warszawa.

Karpowicz Agnieszka (2012), Proza życia. Mowa, pismo, literatura

(Białoszewski, Stachura, Nowakowski, Anderman, Redliński, Schubert), wuw, Warszawa.

Kristeva Julia (2007), Czarne stońce. Depresja i melancholia, przeł. Michał Paweł Markowski, Remigiusz Ryziński, Kraków.

Kunz Tomasz (2006), „Ja: pole do przepisu”. Miron Białoszewski, czyli literatura jako forma istnienia, „Teksty Drugie”, nr 5.

Kwiatkowski Jerzy (1964), Abulia i liturgia, w: tegoż, Klucze do wyobraźni, Warszawa.

Lipszyc Adam (2014), Nicowanie torebek, odkładanie świąt, przesadzanie topoli: od Benjamina do Biatoszewskiego, w: Konstelacje. Sztuka i doświadczenia nowoczesności, red. Daniel Muzyczuk, Paweł Polit, Muzeum Sztuki w Łodzi, Łódź.

Nancy Jean-Luc (2007), Listening, przeł. Charlotte Mandell, Fordham University Press, New York [Stany Zjednoczone].

Nycz Ryszard (2001), „Szare eminencje zachwytu”. Miejsca epifanii w poetyce Białoszewskiego, w: tegoż, Literatura jako trop rzeczywistości. Poetyka epifanii w nowoczesnej literaturze polskiej, Wydawnictwo Universitas, Kraków. 
Sandauer Artur (1968), Poezja rupieci, w: Samobójstwo Mitrydatesa, Czytelnik, Warszawa.

Wiśniewski Jerzy (2004), Miron Białoszewski i muzyka, Wydawnictwo Uniwersytetu Łódzkiego, Łódź 2004.

\section{Aldona Kopkiewicz}

\section{Noises, echoes, oho! Hearing and other senses in Miron} Białoszewski's poetry

The very relation between possibility of writing and sensitivity is a main concern of this interpretation of Miron Białoszewski's poetry. At the start, I notice traumatic state of writing subjectivity, which I see as a negative affect. Białoszewski's trauma manifests itself as an acedia in the Leżenia poetry cycle, in which the poet searches for another, positive affective simulation as well. He finds it in the very work of language, of sounds, and of material reality surrounding him. As he tries to revive himself and his writing mainly through the senses of touching and hearing/listening, I use the model of subjectivity described by Jean-Luc Nancy in the essay On listening, to understand how creative, writing subjectivity works on sensual and language levels.

Keywords: affect; trauma; senses; melancholy; poetry after 1945; modern poetry; postphenomenology; corporeal subjectivity.

Aldona Kopkiewicz - doktorantka na Wydziale Polonistyki uJ, interesuje się filozofią cielesności i poezją nowoczesną. Przygotowuje rozprawę doktorską o afektach, zmysłach i języku poetyckim pod opieką prof. Anny Łebkowskiej. 
